\title{
Managemental Factors Influencing Anestrus Problems in Dairy Cows
}

Soniya Akter Nishi ${ }^{{ }^{*}}$, Md. Jalal Uddin Sarder ${ }^{1}$, Md. Hemayatul Islam ${ }^{1}$, Md. Josim Uddin ${ }^{1}$ and Shyla Sharmin ${ }^{2}$

${ }^{1}$ Department of Veterinary and Animal Sciences, University of Rajshahi, Bangladesh

${ }^{2}$ Department of Livestock Services, Ministry of Fishery and Livestock, Bangladesh

*Corresponding author: Soniya Akter Nishi, Department of Veterinary and Animal Sciences, University of Rajshahi, Rajshahi-6205, Bangladesh, Tel: 008801711156378; E-mail: soniyaakternishi13@gmail.com

Received date: May 19, 2018; Accepted date: July 04, 2018; Published date: July 11, 2018

Copyright: (C2018 Nishi SA, et al. This is an open-access article distributed under the terms of the Creative Commons Attribution License, which permits unrestricted use, distribution, and reproduction in any medium, provided the original author and source are credited.

\begin{abstract}
This study was carried out to determine the prevalence of anestrus problems in dairy cows associated with managemental factors such as housing system, feed quality, deworming and health management of dairy cows. Data were collected by interviewing the owner of the cows using questionnaires from selected private dairy farms and Rajshahi Dairy and Cattle Improvement Farm (RDCIF) at Rajshahi district during the period from January 2016 to December 2016. A total of 500 dairy cows were surveyed to find out the prevalence of anestrus problems in relation to housing system, feed quality, deworming and health management of cows. The raw data were then sorted, computed, coded and statistically analyzed with the help of latest version of SPSS statistics software package. Our findings revealed that, the overall prevalence of anestrus in cows was $40.2 \%$. The housing system, feed quality, deworming and health management of cows influenced the prevalence of anestrus in cows. The prevalence of anestrus was the highest in poor housing system (45.16\%) and the lowest in good housing system (36.17\%). The prevalence of anestrus was not significantly $(P>0.05)$ influenced by the housing systems. Good quality of feed showed the lowest occurrence of anestrus problems $(28.82 \%)$ and poor quality of feed showed the highest occurrence of anestrus problems $(78.72 \%)$. The prevalence of anestrus in dairy cows was significantly $(P<0.05)$ influenced by the feed quality of cows. It was observed that the incidence of anestrus was higher in no deworming measure of farm $(56.96 \%)$ and lower was in regular deworming measure of farm $(29.64 \%)$. The prevalence of anestrus was higher in no preventive measure of dairy cows $(50.95 \%)$ and lower was in regular preventive measure of dairy cows $(29.92 \%)$. Deworming and preventive measures had also significant $(P<0.05)$ effect on anestrus problems in dairy cows.
\end{abstract}

Keywords: Dairy cows; Anestrus; Deworming; Incidence and Management factors

\section{Introduction}

Bangladesh is an agricultural country and most of its 16 million inhabitants live in the rural area. Livestock plays a crucial role in the agricultural economy. Although the GDP contribution of this sector is estimated at $3 \%$, it will exceed $15 \%$ if the total contributions of livestock are considered. Livestock is one of the four major components of agriculture, with crops, fisheries and forestry. Livestock has an important role in poverty reduction, employment generation, and empowerment of women and sustainable development of the country in spite of limited cultivable land. Livestock is an integral part of the smallholder subsistence farming, and an important source of nutrition. Livestock contributes to national GDP through production of milk, meat, hide, skin and eggs. The country earns about $13 \%$ of foreign exchange through hide and skins export [1]. The sector supplies $42.5 \%$ of the animal protein in the form of milk, meat and eggs [2]. Among the livestock, cattle in Bangladesh form an inseparable and integral part of agriculture and it ranks twelfth in cattle population in the world and third in Asia, but it yields only $21 \%$ of milk production and $34 \%$ of beef production in the world [3]. The condition of livestock in Bangladesh is probably the worst in Asia. Livestock in Bangladesh include 22.9 million cattle, 1.2 million buffalo, 20.7 million goat, 2.7 million sheep, 206.9 million chicken and 39.1 million ducks [4]. Cattle and buffalo increased in 1960-1989 at 0.3 and $1.1 \%$, respectively [5]. The number of livestock is not low in proportion to the 160 million human populations, but the major problem lies in the low output. The average milk yield of indigenous dairy cows is only 137 litres per lactation [6] mainly due to poor genetic potential. It is estimated that daily per capita requirement of milk is $250 \mathrm{ml}$ and annual requirement 12.5 million MT [4]. But the present daily per capita availability is only $45 \mathrm{ml}$ and total annual production in 2006-2007 is 2.3 million MT. To meet the deficit, every year government imports milk and its products. Seventeen thousand MT powder milk was imported, costing about Taka: 2000 million (\$29 M) in 2000-2001 [4]. So, an attempt was made to reduce this deficit by establishing private dairy farms and to improve local stock through upgrading by cross-breeding. But reproductive problems like anestrus in cows were the great economic problems. These disorders were major causes of reduced fertility in cows that result in failure to produce or delay in producing the total annual calf crop. It has a negative effect on efficient milk production; pregnancy and parturition were prerequisite for the initiation and maintenance of lactation. About one thirds of total cows were culled in many developed country due to fertility problems [7]. A period of anestrous following parturition was a normal physiological event and the ovarian cyclicity resumes as the involution of uterus was completed. When postpartum anestrous period exceeds 60 days, it increases the service period and consequently the calving interval and also makes dairying an unprofitable business. 
Citation: Nishi SA, Sarder MJ, Islam MH, JosimUddin M, Sharmin S (2018) Managemental Factors Influencing Anestrus Problems in Dairy Cows. J Vaccines Vaccin 9: 393. doi:10.4172/2157-7560.1000393

Page 2 of 4

\section{Materials and methods}

\section{Study area}

Initially the dairy cows were selected from different places at Rajshahi district (Kazla, Bohrompur, Bullonpur, Kumarpara, Rajpara, Baneswar, Kashiadanga, Shalbagan, Shopura, Kathalbaria, Beelpukur, Nawdapara, Buthpara etc.) and RDCIF.

\section{Selection of animals}

Different breeds of dairy cows from heifer and up to 5 parities an absolutely for dairy purpose was considered as experimental materials for this study. Extensive survey and data was collected from private dairy farms and RDCIF. A total of 500 dairy cows were surveyed among Rajshahi district and RDCIF, Rajabarihat for successful completion.

\section{Grouping of selected cows}

To achieve the goal, animals were grouped according to following considering factors:

\section{Housing system}

The housing system of dairy cows were divided into 3 groups

Group I (Poor): The cows were kept in farm with traditional floor $(\mathrm{n}=62)$

Group II (Medium): The cows were kept in farm with little facilities of concrete floor and manger but not scientifical made and poor drainage system $(\mathrm{n}=297)$

Group III (Good): The cows were kept in farm with concrete floor, scientifically made and good drainage system $(n=141)$

\section{Feed quality}

On the basis of feed quality the studied cows were divided into the following groups

\begin{tabular}{lll} 
Group I (Poor): & $:$ & Cows were traditional feed supply (only grazing and little straw feeding) $(\mathrm{n}=94)$ \\
Group II(Medium): & $:$ & The cows were supplied some concentrate and straw $(n=125)$ \\
Group III (Good): & $: \quad \begin{array}{l}\text { The cows were supplied balanced feed (concentrate, vitamin and mineral mixture before calving) diet including } \\
\text { green grass and straw }(n=281)\end{array}$ \\
\hline
\end{tabular}

\section{Deworming of cows}

The cows were divided according to the following deworming measures

Group I (Regular): Every 2 months interval $(\mathrm{n}=280)$

Group II (Irregular): Without follow the schedule $(n=55)$
Group II (None): No deworming ( $\mathrm{n}=165)$

\section{Preventive measure of cows}

The studied cows were divided according to the following preventive measures

\begin{tabular}{lll}
\hline Group I (Regular): & $:$ & Every 2 months interval $(n=254)$ \\
Group II (Occasionally): & $:$ & Without follow the schedule $(n=36)$ \\
Group III (None): & $:$ & No preventive measure of cows $(n=210)$
\end{tabular}

\section{Determination of anestrus cows}

Anestrous cattle was selected as when the cows fail to mate even if it has attained 2.5 years old in case of crossbred heifer and $36^{\text {th }}$ months in case of local heifer, but in case of cows of 60 days have passed since the last delivery.

\section{Data collection procedure}

Firstly a pretested questionnaire was developed for data collection. The survey and data was collected from the selected farms of Rajshahi district and Govt. dairy farm using questionnaires to find out the prevalence of anestrus problems in relation to housing system, feed quality, deworming and preventive measureof cows.The data was collected directly from farmers using questionnaire and diagnosis of anestrus was made on the basis of the history, clinical signs and gynaecological examination by rectal palpation (RP).

\section{Statistical analysis}

The raw data were sorted, computed, coded and statistically analyzed to calculate the prevalence of anestrus due to housing system, feed quality, deworming and health management of cows.Collected data were compiled by Statistical Package for Social Science (SPSS) software 17.0 version [8]. Statistically analyzed by Duncan Multiple range test used to know the association between different groups in respective cases. $\mathrm{P}<0.05$ was considered as significant.

\section{Results and Discussion}

Anestrus is the most important cause of poor reproductive performance in cattle. It is also a big reproductive problem in modern dairy cow production worldwide. In present study, $40.2 \%$ anestrus syndrome was recorded [9] reported the incidence of anestrus (20.4\%) [10], reported the higher prevalence of anestrus $49.9 \%$ in cows which is little bit higher than the present study [11], also reported very high incidence of anestrus. The lower prevalence of anestrus may be due to 
difference in the number of sample size, farm management and breeds of cattle by suppressing estrus and ovulation.

\section{Effect of housing system on the prevalence of anestrus in dairy cows}

Effect of housing system on the prevalence of anestrus in dairy cows is shown in Table 1. It was observed that, the prevalence of anestrus was the highest in poor housing system $(45.16 \%)$ and the lowest in good housing system (36.17\%). The prevalence of anestrus was not significantly $(\mathrm{P}>0.05)$ influenced by the housing system. There is ample evidence that dry and cool environment favors the reproductive efficiency of the cow [12]. Further, the demand and humid environment as caused by poor ventilation favors microbial growth and may work as stressor for the animals [13]. The high incidence of anestrus in the animals of badly ventilated house may be due to high microbial activity and a stressful environment for the animals concerned. Therefore, it can be suggested that a well ventilated housing system is required to maintain a healthy population of cows with good reproductive performance (Table 1).

\begin{tabular}{|l|l|l|l|l|}
\hline Housing system & $\begin{array}{l}\text { Normal cows } \\
\mathbf{n}(\%)\end{array}$ & $\begin{array}{l}\text { Anestrus } \\
\text { cows } \mathbf{n}(\%)\end{array}$ & F-value & P-value \\
\cline { 1 - 3 } Poor $\mathbf{n = 6 2}$ & $34(54.83)$ & $28(45.16)$ & \multirow{2}{*}{ F=0.829 } & \multirow{2}{*}{$\mathrm{P}=0.433$} \\
\cline { 1 - 3 } Medium $\mathbf{n = 2 9 7}$ & $175(58.92)$ & $122(41.07)$ & & \\
\cline { 1 - 3 } Good $\mathbf{n = 1 4 1}$ & $90(63.82)$ & $51(36.17)$ & & \\
\cline { 1 - 3 } Total $\mathbf{n = 5 0 0}$ & $299(59.8)$ & $201(40.2)$ & & \\
\hline
\end{tabular}

Table 1: Effect of housing system on the prevalence of anestrus in dairy cows.

\section{Effect of feed quality on the prevalence of anestrus in dairy cows}

The prevalence of anestrus on feed quality of cows is presented in Table 2. It was observed that, the prevalence of anestrus was higher in poor quality of feed $(78.72 \%)$ and lower was in good quality of feed $(28.82 \%)$. The prevalence of anestrus in dairy cows was significantly $(\mathrm{P}<0.05)$ influenced by the feed quality of cows. Similarly, Sarder [14] reported that the lowest reproductive disorders for excellent quality feed with the highest in poor quality of feed. In accordance to the present study, good nutritional status at periparturient time reduces the postpartum anestrus period in cows [15]. The number of services required per conception depends on the nutritional value of the cow [16]. The negative energy balance in the late pregnancy and early lactation suppresses the pulsatile release of luteinizing hormone and thereby results in reduced ovarian function $[17,18]$. Maintaining a feeding standard enough to supply proper nutrition is important for reproductive performance as well as for milk production in the dairy cows [19]. However, Kamal [20] stated that milk yield is closely associated with dry matter intake and energy intake accounted for most of the variation in energy balance in postpartum cow (Table 2).

\begin{tabular}{|l|l|l|l|l|}
\hline Feed quality & $\begin{array}{l}\text { Normal cows } \mathbf{n} \\
\mathbf{( \% )}\end{array}$ & $\begin{array}{l}\text { Anestrus cows } \\
\mathbf{n}(\%)\end{array}$ & F-value & P-value \\
\hline Poor $\mathbf{n = 9 4}$ & $20(21.27)$ & $74(78.72)^{\mathrm{a}}$ & $\mathrm{F}=42.998$ & $\mathrm{P}=0.000$ \\
\hline $\begin{array}{l}\text { Medium } \\
\mathbf{n = 1 2 5}\end{array}$ & $79(63.2)$ & $46(36.8)^{\mathrm{b}}$ & & \\
\hline
\end{tabular}

\begin{tabular}{|c|c|c|}
\hline Good $n=281$ & $200(71.17)$ & $81(28.82)^{c}$ \\
\hline Total $n=500$ & $299(59.8)$ & $201(40.2)$ \\
\hline
\end{tabular}

Table 2: Effect of feed quality on the prevalence of anestrus in dairy cows ( $\mathrm{n}=500)$; (Values are $\%, \mathrm{n}=$ Number of observation; the values are $\mathrm{a}, \mathrm{b}$ and $\mathrm{c}$ with different superscript letters in same column differ significantly with each other's $(\mathrm{P}<0.05)$. $\mathrm{F}=$ Factorial, $\mathrm{P}=$ Probability $)$.

\section{Effect of deworming on the prevalence of anestrus in dairy cows}

The effect of deworming on the prevalence of anestrus in dairy cows is summarized in Table 3. It was observed that, the prevalence of anestrus was higher in no deworming measure of farm (56.96\%) and lower was in regular deworming measure of farm (29.64\%). Deworming measure had significant $(\mathrm{P}<0.05)$ effect on anestrus problems in dairy cows (Table 3).

\begin{tabular}{|l|l|l|l|l|}
\hline Deworming & $\begin{array}{l}\text { Normal cows } \mathbf{n} \\
(\%)\end{array}$ & $\begin{array}{l}\text { Anestrus cows } \\
\mathbf{n}(\%)\end{array}$ & F-value & P-value \\
\cline { 1 - 2 } $\begin{array}{l}\text { Regular } \\
\mathbf{n}=\mathbf{2 8 0}\end{array}$ & $197(70.3)$ & $83(29.64)^{\mathrm{c}}$ & & \\
\cline { 1 - 3 } $\begin{array}{l}\text { Irregular } \\
\mathbf{n}=\mathbf{5 5}\end{array}$ & $34(61.81)$ & $21(38.18)^{\mathrm{b}}$ & \multirow{2}{*}{$\mathrm{F}=17.306$} & $\mathrm{P}=0.000$ \\
\cline { 1 - 2 } None $\mathbf{n = 1 6 5}$ & $71(43.03)$ & $94(56.96)^{\mathrm{a}}$ & & \\
\cline { 1 - 3 } Total $\mathbf{n = 5 0 0}$ & $299(59.8)$ & $201(40.2)$ & & \\
\hline
\end{tabular}

Table 3: Effect of deworming on the prevalence of anestrus in dairy cows $(n=500)$; (Values are $\%, n=$ Number of observation; the values are $\mathrm{a}, \mathrm{b}$ and $\mathrm{c}$ with different superscript letters in same column differ significantly with each other's $(\mathrm{P}<0.05)$. $\mathrm{F}=$ Factorial, $\mathrm{P}=$ Probability $)$.

\section{Effect of health management on the prevalence of anestrus in dairy cows}

The effect of health management on anestrus in dairy cows is presented in Table 4. It was observed that, the prevalence of anestrus was higher in no preventive measure of dairy cows (50.95\%) and lower was in regular preventive measure of dairy cows (29.92\%). Preventive measure had significant $(\mathrm{P}<0.05)$ effect on anestrus problems in dairy cows. However, Kamal [20] stated that managemental system including the farm staffs, who have a standard operating procedure for estrus detection, realized a marginally higher (73\%) detection rate by observing the animals during four 20 min observational periods per 24 $\mathrm{h}$ period, with additional observations during the milking periods (Table 4).

\begin{tabular}{|c|c|c|c|c|}
\hline $\begin{array}{l}\text { Health } \\
\text { managemen } \\
t\end{array}$ & $\begin{array}{l}\text { Normal cows } n \\
(\%)\end{array}$ & $\begin{array}{l}\text { Anestrus cows } \\
\mathrm{n}(\%)\end{array}$ & F-value & P-value \\
\hline $\begin{array}{l}\text { Regular } \\
n=254\end{array}$ & $178(70.07)$ & $76(29.92)^{b}$ & \multirow{3}{*}{$F=11.819$} & \multirow{3}{*}{$P=0.000$} \\
\hline $\begin{array}{l}\text { Occasionall } \\
\text { y } n=36\end{array}$ & $18(50)$ & $18(50)^{a}$ & & \\
\hline None $n=210$ & $103(49.04)$ & $107(50.95)^{\mathrm{a}}$ & & \\
\hline
\end{tabular}


Citation: Nishi SA, Sarder MJ, Islam MH, JosimUddin M, Sharmin S (2018) Managemental Factors Influencing Anestrus Problems in Dairy Cows. J Vaccines Vaccin 9: 393. doi:10.4172/2157-7560.1000393

Page 4 of 4

\begin{tabular}{|l|l|l|l|l|}
\hline Total $\mathbf{n}=\mathbf{5 0 0}$ & $299(59.8)$ & $201(40.2)$ & & \\
\hline
\end{tabular}

Table 4: Effect of health management on the prevalence of anestrus in dairy cows $(n=500)$; (Values are $\%, n=$ Number of observation; the values are $\mathrm{a}, \mathrm{b}$ and $\mathrm{c}$ with different superscript letters in same column differ significantly with each other's $(\mathrm{P}<0.05)$. $\quad \mathrm{F}=$ Factorial, $\mathrm{P}=$ Probability).

\section{Conclusion}

Results of the present study led to the following conclusions

-The prevalence of anestrus was the highest in poor housing system (45.16\%) and the lowest in good housing system (36.17\%).

-Good quality of feed showed the lowest occurrence of anestrus problems $(28.82 \%)$. The prevalence of anestrus in dairy cows was significantly $(\mathrm{P}<0.05)$ influenced by the feed quality of cows.

-Deworming and preventive measures had also significant $(\mathrm{P}<0.05)$ effect on anestrus problems in dairy cows.

\section{Acknowledgements}

The authors acknowledge the Department of Veterinary and Animal Sciences, University of Rajshahi, Bangladesh and the owner of dairy farms of Bangladesh was help to give data and competitions of the study.

\section{References}

1. Alam J (1991) Livestock development strategies in Bangladesh. The Socioeconomic Perspective. Proceeding of workshop on Livestock Development in Bangladesh.

2. BBS (1998) Structure of Agricultural holding and livestock population Statistical Division.

3. Alam J, Akteruzzaman M, Rahman A, Ahmed Z (1994) Comparative performance of local and crossbred cows in Bangladesh. Indian J Dairy Sci 47: 112-117.

4. DLS (2008) A report of livestock. Department of Livestock Services, Dhaka.

5. Alam J (1995) Livestock resources in Bangladesh: Present status and future potential.
6. DLS (1991) A report of livestock. Department of Livestock Services.

7. Talukder MAS, Khandoker MAMY, Rahman MGM, Islam MR, Khan MAA (2005) Reproductive problems of cows at Bangladesh Agricultural University Dairy Farm and Possible Remedies. Pak J Biol Sci 8: 1561-1567.

8. Sarder MJU, Moni MIZ, Akhter S (2010) Prevalence of reproductive disorders of crossbred cows in the Rajshahi District of Bangladesh. SAARC J Agri 8: 65-75.

9. Serur BH, Farrag AA, Gomaa A (1982) Incidence of certain infertility problems among cows and buffaloes in Upper Egypt. Assoc Vet Med J 10: 209-214

10. Rahman MF, Hossain MS, Prodhan MAM (1993) Reproductive problems of cattle in Bangladesh. Bangladesh Veterinarian 10: 71-73.

11. Clark JA (1981) Health problem in intensive animal production. In: Environmental Aspect for Housing for animal production.

12. Selye, Michel TB (1986) Determinants of disease. In: Veterinary Epidemiology.

13. Sarder MJU (2008) Occurrence of reproductive disorders in crossbred cows of north Bangladesh.

14. Peters AR, Riley GM (1982) Milk Progesterone Profiles and factors affecting postpartum ovarian activity in beef cows. Animal production 34: $145-153$.

15. Butler WR, Smith RD (1989) Inter-relationship between energy balance and postpartum reproductive function in dairy cattle. J Dairy Sci 72: 767-783.

16. Tomar OS, Sharma PA, Verma GS, Nagpaul Pk (1985) Effect of nutrition of growth reproductive performance and milk production in Karan-Swiss animals world. Rev Anim Prod 21: 45-48.

17. Dobson H, Alam MGS (1987) Preliminary investigation into the endocrine system of subfertile cattle: location of a common lesion (rate limiting step). J Endocrinol 113: 167-171.

18. Butler WR, Smith RD (1989) Interrelationships between energy balance and postpartum reproductive function in dairy cattle. J Dairy Sci 72: 767-783.

19. Sasser RG, Williams RT, Bull RC, Ruder CA, Falk DG (1988) Postpartum reproductivity performance in crude protein restricted beef cows: return to estrus and conception. J Anim Sci 66: 3033-3039.

20. Kamal MM, Bhuiyan MMU, Parveen N, Momont HW, Shamsuddin M (2014) Risk factors for postpartum anestrus in crossbred cows in Bangladesh. Turk J Vet Anim Sci 38: 151-156. 